\title{
白洋淀浮游植物群落及其与环境因子的典范对应分析”
}

\author{
沈会涛 ${ }^{1}$, 刘存歧 ${ }^{2 * *}$ \\ (1: 华东师范大学环境科学系, 上海 200062) \\ (2: 河北大学生命科学学院, 保定 071002)
}

摘 要: 为掌握白洋淀浮游植物的群落特征, 于 2006 年 4 月至 10 月间对其进行了 5 次采样调查, 经显微镜检, 共鉴定出浮游植 物 155 种(属), 浮游植物的密度范围在 $55.5 \times 10^{4}-1704.8 \times 10^{4}$ cells $/ \mathrm{L}$ 之间, 群落组成以蓝藻、隐藻和绿藻为主. 应用 CANOCO 4.5 软件对获得的浮游植物数据和环境因子数据进行典范相关分析 $(\mathrm{CCA})$, 作出物种与环境因子关系的二维排序图. 结果表明, 水 体中的 $\mathrm{pH}$ 值及总磷浓度是影响这一区域物种分布格局重要因素, 除此之外, 生物需氧量和溶氧量也对浮游植物的分布有较大 影响. CCA 排序图较好的说明了浮游植物物种分布和环境因子之间的关系.

关键词：浮游植物；环境因子; 典范对应分析; 白洋淀

\section{Canonical correspondence analysis of phytoplankton community and its environmental factors in the Lake Baiyangdian}

\author{
SHEN Huitao ${ }^{1} \&$ LIU Cunqi ${ }^{2}$ \\ (1: Department of Environmental Science, East China Normal University, Shanghai 200062, P.R.China) \\ (2: College of Life Science, Hebei University, Baoding 071002, P.R.China)
}

\begin{abstract}
The phytoplankton community in the Lake Baiyangdian was characterized based on, five surveys were carried out from April to October in 2006. A total of 155 taxa were identified by microscope. The phytoplankton had an abundance ranging from $55.5 \times 10^{4} \mathrm{cells} / \mathrm{L}$ to $1704.8 \times 10^{4} \mathrm{cells} / \mathrm{L}$. The phytoplankton community was dominated by Cyanophyta, Cryptophyta and Chlorophyta. Canonical correspondence analysis (CCA) was applied to explore the relationship between phytoplankton species and environmental parameters by CANOCO 4.5. The species - environment biplots were drawn based by the result of CCA. The result showed that $\mathrm{pH}$ and total phosphorus were the most important factors influencing the distribution of phytoplankton species. Besides these, biochemical oxygen demand and dissolved oxygen were also important to the phytoplankton species. CCA ordination shows a slight, but significant method to understand the relationship between spatial distribution of phytoplankton community and environmental factors in lake systems.
\end{abstract}

Keywords: Phytoplankton; environmental factors; canonical correspondence analysis; Lake Baiyangdian

浮游植物是水环境中的初级生产者和食物链的基础环节 ${ }^{[1]}$, 在水生态系统的研究中具有重要的意义. 浮游植物与环境之间有着十分密切的关系, 其种类的组成和分布变化对环境的变化具有指示作用, 同时环 境条件的改变也直接或间接地影响到浮游植物的群落结构 ${ }^{[2]}$.

典范对应分析(Canonical Correspondence analysis, CCA)是一种非线性多元直接梯度分析方法, 它把对 应分析与多元回归结合起来 ${ }^{[3]}$. 不同于以前的直接梯度分析, CCA 可以结合多个环境因子, 包含的信息量 大, 结果直观明显, 从而更好地反映群落与环境的关系 ${ }^{[4]}$. 近年来, CCA 被广泛应用于浮游植物群落与环 境因子间复杂关系的研究 ${ }^{[5-6]}$.

* 河北省科学技术研究与发展指导计划(06276905)资助. 2008-04-15 收稿; 2008-07-14 收修改稿. 沈会涛, 男, 1980 年生, 博 士研究生; E-mail: shenhuitao80@126.com.

** 通讯作者; E-mail: liucunqi@sina.com. 
白洋淀位于河北省中部, 面积 $366 \mathrm{~km}^{2}$, 是华北地区最大的内陆淡水湖泊 ${ }^{[7]}$. 本文在 2006 年对白洋淀 浮游植物群落和环境参数调查和测定的基础上，运用典范对应分析来探讨浮游植物分布与环境因子之间 的关系, 从而为利用浮游植物进行水质监测工作提供方法和相关参考.

\section{1 材料和方法}

\section{1 采样时间和采样点设置}

采样时间为 2006 年 4 月、 5 月、 7 月、9 月和 10 月. 采样点设置: 在白洋淀共设置 8 个样点(图 1), 代表了白洋淀湿地环境的总体特征. 1-3 号采样点(端村、采蒲台、圈头)位于淀区开放水面，不受府河 污水排放的影响, 端村、圈头为养鱼区, 水产养殖业发达; 采蒲台为静水蓄积区, 离村落较远, 受人类 活动影响较小, 生长有大量挺水植物和沉水植物. 4 号点(光淀)为半养鱼区, 水产养殖业较发达, 水草丰 盛. 5 号点(㫫林庄)为淀区出水口, 离污染源较远, 水质较好. 6 号点(王家寨)为畜禽养殖区, 并且旅游业 发达, 受人类活动影响大, 水质差. 7 号点(烧车淀)为静水蓄积区, 水面开阔, 养殖业和种植业都较发达. 8 号点(南刘庄)为污水河流人口, 接受来自府河排放的污水和安新县的工业及生活污水, 水体富营养化 的程度较高.

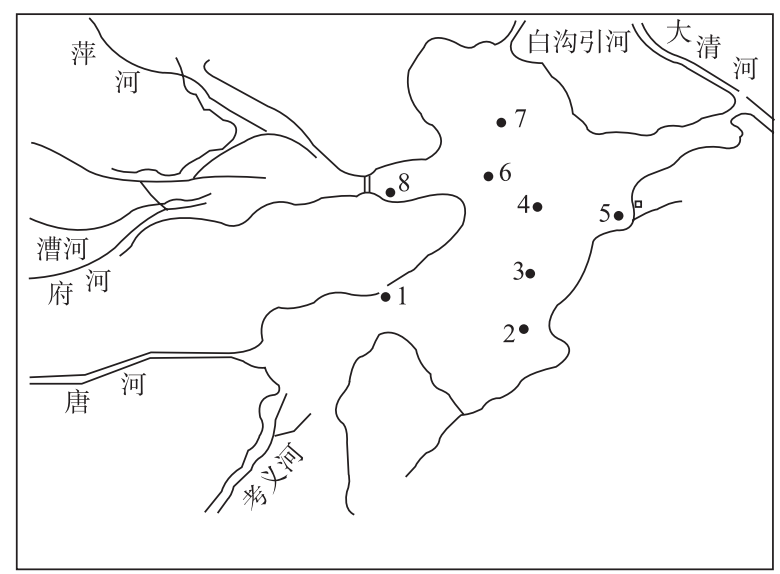

图 1 白洋淀采样点示意图

Fig.1 Sampling sites of the Lake Baiyangdian

\section{2 样品的采集、处理和分析}

水样的采集、浮游植物物种鉴定和计数等参考有关书籍 ${ }^{[8-10]}$. 各样点的理化因子: $\mathrm{pH}$ 值、溶解氧(DO)、 化学需氧量 $\left(\mathrm{COD}_{\mathrm{Cr}}\right)$ 、生物需氧量 $(\mathrm{BOD})$ 、总磷 $(\mathrm{TP})$ 、总氮 $(\mathrm{TN})$ 、高锰酸钾指数 $\left(\mathrm{COD}_{\mathrm{Mn}}\right)$, 采用保定市环 保局环境监测中心提供的数据.

\section{3 数据分析}

采用 PRIMER 5.0 软件对白洋淀浮游植物群落的 Shannon-Wiener 多样性指数、Margalef 丰富度指数、 Pielou 均匀度指数进行计算 ${ }^{[11]}$.

采用 Canoco for Windows 4.5 软件对物种数据和环境数据进行 CCA 分析. 物种数据要经过篮选, 本 文用于排序的物种要求满足下面两个条件：该物种在各样点出现的频度 $>12.5 \%$, 该物种在至少一个样 点的相对密度 $\geqslant 1 \%{ }^{[12-13]}$. 物种矩阵经过 $\lg (x+1)$ 转换, 环境数据除 $\mathrm{pH}$ 值以外都进行 $\lg (x+1)$ 转换 ${ }^{[13-14]}$, 利用 Canoco for Windows 软件包中的 WcanoImp 将其分别生成名为 spe.dta 和 env.dta的文件. 应用 Canoco for Windows 4.5 进行运算, 将生成的数据文件 spe-env.cdw 在 Canodraw for Windows 中作图, 排序结果用 物种-环境因子关系的双序图表示 ${ }^{[15]}$. 


\section{2 结果与分析}

\section{1 环境因子}

白洋淀各样点的环境因子平均值月份变化如表 1 所示. $\mathrm{pH}$ 值在 7.790-8.565 之间变化, 4 月 $\mathrm{pH}$ 值 最低, 而 5 月最高. 溶氧量 7 月最高为 $10.238 \mathrm{mg} / \mathrm{L}$, 而 10 月最低. 化学需氧量和生物需氧量均在 4 月 出现最高值, 分别为 $76.713 \mathrm{mg} / \mathrm{L}$ 和 $19.671 \mathrm{mg} / \mathrm{L}$. 总磷浓度在 $0.09-0.34 \mathrm{mg} / \mathrm{L}$ 之间变化, 而总氮浓度在 1.879-12.788mg/L 之间变化, 营养盐浓度整体上表现出了 4 月高于其它采样月份. 高镇酸钾指数平均值为 $12.729 \mathrm{mg} / \mathrm{L}$, 其中在 4 月和 7 月较高, 分别为 $17.124 \mathrm{mg} / \mathrm{L}$ 和 $14.385 \mathrm{mg} / \mathrm{L}$, 其余采样月份中差别不大.

\section{2 浮游植物种类组成与数量分布}

2.2.1 种类组成及优势种变化 调查期间, 共检测到浮游植物 8 门, 155 种, 其中, 其中绿藻门最多, 为 81 种, 占 $52.3 \%$; 蓝藻门 29 种, 占 $18.7 \%$; 硅藻门 17 种, 占 $11.0 \%$; 裸藻门 14 种, 占 $9.0 \%$; 甲藻门 6 种, 占 $3.9 \%$; 黄藻门 4 种，占 $2.6 \%$; 隐藻门 3 种，占 $1.9 \%$; 金藻门最少, 仅有 1 种, 占 $0.6 \% .4$ 月份优势种有隐 藻门的卵形隐藻 (Cryptomonas ovata), 出现频度为 $100 \%$; 亚优势种为隐藻门的马氏隐㩰 (Cryptomonas marssonii)、绿藻门的小球藻(Chlorella vulgaris)和硅藻门的针杆藻(Synedra sp.), 出现频度均为 $100 \%$. 5 月份优势种有隐藻门的卵形隐藻和马氏隐藻, 出现频度均为 $100 \%$; 亚优势种为蓝藻门的细小平裂藻 (Merismopedia tenuissima) 和硅藻门的针杆藻, 出现频度分别为 $87.5 \%$ 和 $100 \% .7$ 月份优势种为蓝藻门的 蓝绿平裂藻(Merismopedia glauca), 出现频度为 $100 \%$; 亚优势种为绿藻门的小球藻和隐藻门的卵形隐藻, 出现频度均为 $100 \% .9$ 月份优势种为隐藻门的卵形隐藻, 出现频度为 $100 \%$; 亚优势种为绿藻门的小球藻 和蓝藻门的细小平裂藻, 出现频度为 $100 \%$ 和 $87.5 \%$. 10 月份优势种为绿藻门的小球藻和蓝藻门的细小平 裂藻, 出现频度均为 $100 \%$; 亚优势种为裸藻门的具尾裸藻(Euglena caudata) 和隐藻门的卵形隐藻, 出现 频度均为 $100 \%$.

表 1 白洋淀水体环境因子变化

Tab.1 The variations of environmental factors in the Lake Baiyangdian

\begin{tabular}{cccccccc}
\hline 日期(年·月 $)$ & $\mathrm{pH}$ & $\mathrm{DO}(\mathrm{mg} / \mathrm{L})$ & $\mathrm{COD}_{\mathrm{Cr}}(\mathrm{mg} / \mathrm{L})$ & $\mathrm{BOD}(\mathrm{mg} / \mathrm{L})$ & $\mathrm{TP}(\mathrm{mg} / \mathrm{L})$ & $\mathrm{TN}(\mathrm{mg} / \mathrm{L})$ & $\mathrm{COD}_{\mathrm{Mn}}(\mathrm{mg} / \mathrm{L})$ \\
\hline 2006.4 & 7.79 & 5.865 & 76.713 & 19.671 & 0.338 & 12.788 & 17.124 \\
2006.5 & 8.565 & 9.726 & 40.75 & 5.896 & 0.09 & 1.879 & 10.64 \\
2006.7 & 8.215 & 10.238 & 35.863 & 5.638 & 0.34 & 4.841 & 14.385 \\
2006.9 & 7.944 & 9.899 & 34.125 & 5.15 & 0.187 & 4.62 & 10.626 \\
2006.10 & 8.134 & 5.618 & 39 & 4.05 & 0.27 & 3.761 & 10.868 \\
平均 & 8.13 & 8.269 & 45.290 & 8.081 & 0.245 & 5.578 & 12.729 \\
\hline
\end{tabular}

2.2.2 浮游植物密度 在调查期内, 浮游植物的密 度范围在 $55.5 \times 10^{4}-1704.8 \times 10^{4} \mathrm{cells} / \mathrm{L}$ 之间，月平 均密度为 $507.82 \times 10^{4} \mathrm{cell} / \mathrm{s} / \mathrm{L}$ (表 2 ). 浮游植物月平 均密度变化大, 平均最高密度 $(9$ 月)与最低密度 $(5$ 月)相差较大. 由图 2 可看出, 1 号、3 号和 8 号样 点浮游植物月平均细胞密度较大, 而 2 号样点最 低, 其余各样点之间相差较小. 8 号样点浮游植物 月平均密度最大, 其次为 3 号样点和 1 号样点, 2 号样点月平均密度最低, 其余各样点相差不大. 南刘庄位于府河人淀口, 水体中有机物质含量较 高, 虽然浮游植物种类较少, 但细胞密度较大, 主要种为耐污种如蓝藻门的小球藻、隐藻门的卵
表 2 白洋淀浮游植物密度变化 $\left(\times 10^{4}\right.$ cells $\left./ \mathrm{L}\right)$ Tab. 2 The seasonal variation of phytoplankton density of the Lake Baiyangdian

\begin{tabular}{ccc}
\hline 日期(年.月) & 均值 & 变幅 \\
\hline 2006.4 & 340.44 & $66.9-731.55$ \\
2006.5 & 300.73 & $65.4-540.45$ \\
2006.7 & 695.96 & $192.15-1648.5$ \\
2006.9 & 755.12 & $248.1-1704.8$ \\
2006.10 & 466.83 & $55.5-895.8$ \\
\hline
\end{tabular}


形隐藻等. 端村和圈头为养鱼区, 水体受投放的饵料等影响较大, 浮游植物密度也偏高. 采蒲台离村落 远, 污染程度较低, 浮游植物种类与密度都较少. 束林庄、光淀、王家寨、烧车淀离村落较近, 污染源主 要来自内源性污染(生活污水和养殖污染), 浮游植物群落细胞密度较为相近.

2.2.3 群落物种多样性 从图 3 可以看出, Shannon-Wiener 指数 $\left(H^{\prime}\right)$ 范围为 3.43-4.33, 1 号、3 号和 8 号样点 指数较低, 2 号样点最高, 其余各样点间差别不大. Margalef 指数 (d) 范围为 2.89-9.56, 2 号和 8 号样点的 Margalef 指数低于其它各样点. Pielou 指数 $(J)$ 变幅为 $0.62-0.81$, 其变化规律与 Shannon-Wiener 指数相同.

\section{3 浮游植物群落与环境因子关系的 CCA 分析}

典范对应分析提供分析浮游植物群落组成与环境因子之间对应关系的工具 ${ }^{[6]}$. 在由主轴 1 和主轴 2 构成的排序图中，环境因子用带有箭头的线段表示，向量长短代表了其在主轴中的作用，箭头所处象限 表示环境因子与排序轴之间相关性的正负 ${ }^{[5]}$. 分析时, 可以做出某一种类(或样点)与环境因子连线的垂直 线, 垂直线与环境因子连线相交点离箭头越近, 表示该种(或该样点)与该类生境因子的正相关性越大, 处 于另一端的则表示与该类环境因子具有的负相关性越大 ${ }^{[16]}$. 对浮游植物的优势种在主轴上排序, 则可反 映这些浮游植物与环境因子之间的对应关系. 根据浮游植物出现频度和相对密度, 选取了 16 种浮游植物 用于 CCA 分析, 浮游植物的代码见表 3.

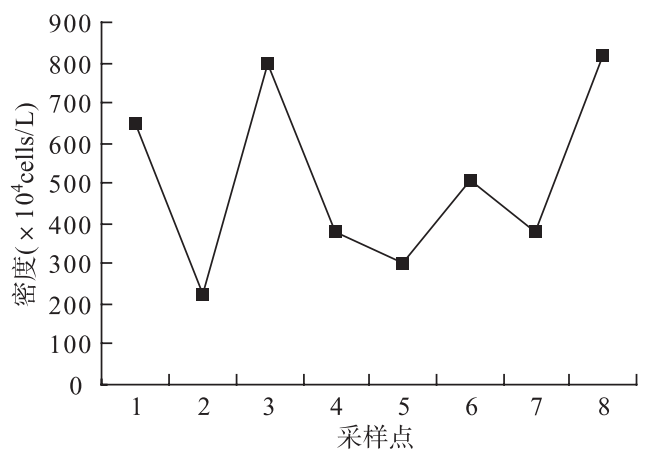

图 2 白洋淀不同样点浮游植物密度比较

Fig.2 The comparison of phytoplankton density of the Lake Baiyangdian

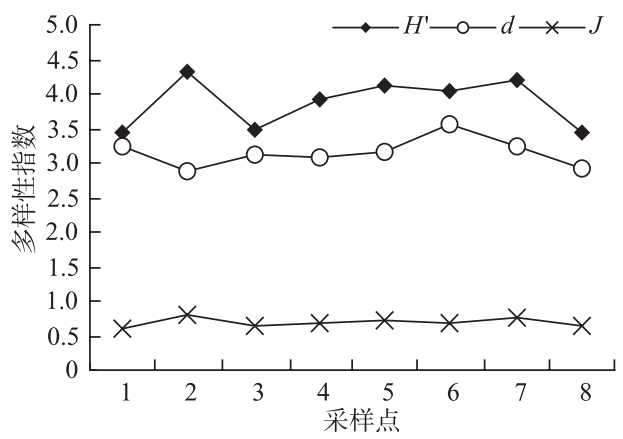

图 3 白洋淀不同样点浮游植物群落多样性指数

Fig.3 Diversity indices of phytoplankton community of 8 sampling sites in the Lake Baiyangdian

表 3 CCA 分析中浮游植物种类代码

Tab.3 Codes of phytoplankton species for CCA

\begin{tabular}{|c|c|c|c|}
\hline & 种类 & & 种类 \\
\hline s1 & 球衣藻(Chlamydomonas sp.) & s9 & 小环藻(Cyclotella sp.) \\
\hline s2 & 小球藻(Chlorella vulgaris) & s10 & 针杆藻(Synedra sp. ) \\
\hline s3 & 螺旋纤维藻(Ankistrodesmus spiralis) & s11 & 最小胶球藻(Gloeocapsa minima) \\
\hline s4 & 鼓藻(Cosmarium sp. ) & s12 & 具尾裸藻(Euglena caudata) \\
\hline s5 & 韦氏藻(Westella botryoides) & s13 & 梭形裸藻(Euglena acus) \\
\hline s6 & 四尾栅藻(Scenedesmus quadricauda) & s14 & 马氏隐藻(Cryptomonas marssonii) \\
\hline s7 & 柱状栅藻 $(S$. bijuga $)$ & s15 & 卵形隐藻 (C. ovata) \\
\hline s8 & 蹄形藻(Kirchneriella sp. ) & s16 & 尖尾蓝隐藻(Chroomonas acuta) \\
\hline
\end{tabular}

图 4 反映了浮游植物与环境因子间的关系，从排序图上明显反映出 16 种浮游植物对环境条件的不同 适应特点. 对于环境因子来讲, 第一、第二排序轴间的相关系数都为 0 , 说明排序结果是可信的 ${ }^{[17-18]}$. 第 
一排序轴与 $\mathrm{pH}$ 值呈正相关 $(0.505)$, 与生物需氧量呈负相关 $(-0.307)$; 第二排序轴与总磷浓度呈正相关 (0.570), 与溶氧量呈负相关 $(-0.383)$. 根据 7 个主要环境因子的分布特征, CCA 排序分析可将 16 中浮游植 物种类分为 3 个组. 种组 I 只包括尖尾蓝隐藻 1 种浮游植物, 与生物需氧量、总磷浓度和总氮浓度正相关, 而与高锰酸钾指数和化学需氧量负相关. 种组 II 包括小球藻、鼓藻、蹄形藻、小环藻、具尾裸藻、卵形 隐藻等 6 种浮游植物, 其分布格局与较高的高锰酸钾指数和化学需氧量有很大的正相关; 并且种组 II 中 的多数浮游植物种类生活在中营养或富营养状态水体中 ${ }^{[19]}$, 在排序图中, 都位于总氮轴和总磷轴附近, 呈正相关. 从第二排序轴可以看出, 种组III中的球衣藻、螺旋纤维藻、韦氏藻、四尾栅藻、柱状栅藻、针 杆藻、最小胶球藻、梭形裸藻、马氏隐藻等 9 种浮游植物, 其分布格局与 $\mathrm{pH}$ 值和溶氧量有着极大的相关 性，由于白洋淀水体呈现明显的偏碱性，同时水体中的溶氧量也偏低，这表明 $\mathrm{pH}$ 值和溶氧量是影响种组 III中浮游植物种类生长的限制条件.

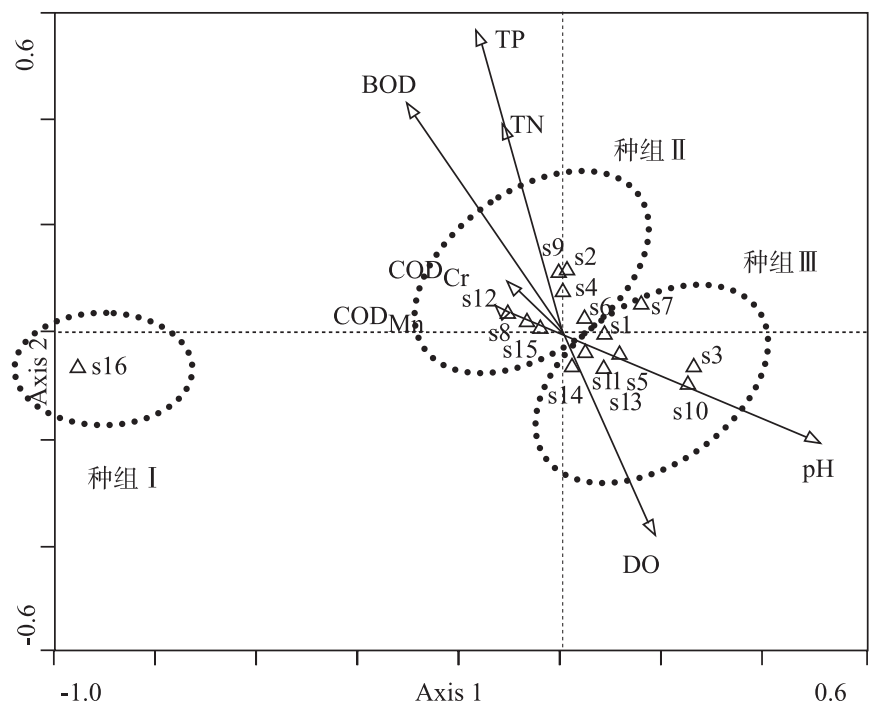

图 4 白洋淀浮游植物物种与环境关系的 CCA 排序图

Fig.4 CCA biplot of phytoplankton species and environmental variables in the Lake Baiyangdian

\section{3 讨论和结论}

2006 年共观察到浮游植物 8 门, 155 种(属), 调查期内浮游植物月平均细胞密度为 $507.82 \times 10^{4} \mathrm{cells} / \mathrm{L}$. 中营养型湖泊中常以甲藻、隐藻、硅藻类占优势, 富营养型湖泊则常以绿藻、蓝藻类占优势 ${ }^{[20]}$. 从白洋 淀浮游植物优势种和亚优势种来看, 除 2 号样点外, 其余各样点浮游植物群落组成以蓝藻门的蓝绿平裂 藻、细小平裂藻, 绿藻门的小球藻以及隐藻门的卵形隐藻和马氏隐藻等占有优势, 说明白洋淀多数水体 处于富营养化状态.

群落物种多样性是群落组织独特的生物学特征, 它反映了群落特有的物种组成和个体密度特征. 湖 泊中的营养盐作为浮游植物赖以增殖的基础, 其数量与分布能影响浮游植物的数量动态; 同样, 作为水 体生态系统的生产者, 浮游植物也能吸收、消耗水体中的营养盐. 1 号、4 号、5 号、6 号和 7 号样点为养 鱼区、半养鱼区和畜离养殖区, 并且离村落较近, 污染源主要来自内源性污染(生活污水和养殖污染), 环 境特征相似, 所以浮游植物多样性指数较为一致; 2 号样点由于离污水人口较远, 并生长有大量挺水植物 和沉水植物, 能够净化水体, 并且远离村庄, 水质较好, 浮游植物种类组成和丰度都较少, 造成 Shannon-Wiener 指数偏高, 而 Margalef 指数偏低; 8 号样点是污水人口, 大量污染性物质排人水体, 导致 水体恶化, 沉水性植物灭绝, 水体自净作用降低, 水体中只能生存耐污种, 种类组成较少, 但个体密度大, 所以多样性指数都偏低. 
张义科等 ${ }^{[21]}$ 应用浮游植物群落资料通过指示生物法、藻商值、营养状态指数和物种多样性指数评价了白 洋淀水质，同时利用理化分析方法对水质进行监测，结果表明，1991-1992 年白洋淀的水质为中性或微碱性贫 营养型水体, 而 1993 年则为碱性富营养型水体. 冯建社 ${ }^{[7]}$ 根据浮游植物的种类组成及种数数量, 利用污染指 示种, 指示群落, 多样性指数三种方法评价白洋淀水质污染状况, 表明白洋淀属于 $\beta$ 中污水体. 在以往对白洋 淀浮游植物群落的研究中, 只是单纯从多样性指数、指示生物等方面对其水质进行了评价, 而未将浮游植 物植物群落与环境因子进行结合. 本文对白洋淀浮游植物群落与环境因子进行了典范对应分析, 结果表 明, $\mathrm{pH}$ 值和总磷浓度是影响这一区域物种分布格局的重要因素. 但不同湖泊具有不同的主要影响因子, Habib 等 ${ }^{[22]}$ 阐明硅酸盐作为重要的环境因子比硝酸盐和硅酸盐对浮游植物群落影响较大, 同时温度、溶 解氧和化学需氧量也是影响浮游植物群落的重要环境因子; Arhonditsis 等 ${ }^{[23]}$ 研究了华盛顿湖表明: 透明 度、总磷和捕食压力对浮游植物的影响最大; Lau 等 ${ }^{[24]}$ 研究表明浮游植物受营养盐(氮、磷和硅)及捕食(浮 游动物和水蚤)作用的影响. CCA 排序较好地解释了物种与环境之间的内在联系，同时也反映出不同物种 的生态分化现象 ${ }^{[3]}$. 在对白洋淀浮游植物群落和环境因子生态调查的基础上，应用典范对应分析对大量 的数据进行直接梯度排序，可以揭示出白洋淀关键浮游植物物种对环境因子的响应，在一定程度上能反 应出湖泊水体的水质状况, 为该地区的浮游植物群落生态学研究提供了一种新的工具; 另外除主要的环 境因子外, 人为干扰(村落排污、底泥疏浚等)、浮游动物的下行效应 ${ }^{[25]}$ 等在很大程度上也影响湖泊内浮 游植物的群落结构.

\section{4 参考文献}

[1] 沈暳芬, 章宗涉, 龚循矩等. 微型生物监测新技术. 北京: 中国建筑工业出版社, 1990.

[2] Lepistö L, Holopainen AL, Vuoristo H. Type-specific and indicator taxa of phytoplankton as a quality criterion for assessing the ecological status of Finnish boreal lakes. Limnologica, 2004, 34: 236-248.

[3] 栾青杉, 孙 军, 宋书群等. 长江口夏季浮游植物群落与环境因子的典范对应分析. 植物生态学报, 2007, 31(3): 445-450.

[4] 张金屯. 植被与环境关系的分析II. CCA和DCCA限定排序. 山西大学学报(自然科学版), 1992, 15(3): 292-298.

[5] Habib OA, Tippett R, Murphy KJ. Seasonal changes in phytoplankton community structure in relation to physico-chemical factors in Loch Lomond, Scotland. Hydrobiologia, 1997, 350: 63-79.

[6] 李秋华, 韩博平. 基于 CCA 的典型调水水库浮游植物群落动态特征分析. 生态学报, 2007, 27(6): 2355-2364.

[7] 冯建社. 白洋淀浮游植物与水质评价. 江苏环境科技, 1999, 2: 27-29.

[8] 黎尚豪, 毕列爵. 中国淡水藻志. 北京: 科学出版社, 1998.

[9] 金相灿, 屠清瑛. 湖泊富营养化调查规范(第二版). 北京：中国环境科学出版社, 1990.

[10] 大连水产学院主编. 淡水生物学. 山东: 农业出版社, 1982.

[11] Clarke KR, Warwick RM. Change in marine communities: an approach to statistical analysis and interpretation(2nd Edition). PRIMER-E: Plymouth, 2001: 2-15.

[12] Lopes MRM, Bicudo CEM, Ferragut MC. Short term spatial and temporal variation of phytoplankton in a shallow tropical oligotrophic reservoir, southeast Brazil. Hydrobiologia, 2005, 542: 235-247.

[13] Muylaert K, Sabbe K, Vyverman W. Spatial and temporal dynamics of phytoplankton communities in a freshwater tidal estuary (Schelde, Belgium). Estuarine, Coastal and Shelf Science, 2000, 50: 673-687.

[14] Flores LN, Barone R. Phytoplankton dynamics in two reservoirs with different trophic state (Lake Rosamarina and Lake Arancio, Sicily, Italy). Hydrobiologia, 1998, 369/370: 163-178

[15] 魏玉莲, 姬兰柱, 王 沝等. 长白山北坡静水水体中水甲虫分布与环境关系的典范对应分析. 应用生态学报, 2002, 13(1): 91-94.

[16] 张元明, 陈亚宁, 张小雷. 塔里木河下游植物群落分布格局及其环境解释. 地理学报, 2004, 59(6): 903-910.

[17] ter Braak CJF. Canonical correspondence analysis: a new eigenvector technique for multivariate direct gradient analysis. Ecology, 1986, 67: 1167-1179.

[18] 郝占庆, 郭水良, 叶 吉. 长白山北坡木本植物分布与环境关系的典范对应分析. 植物生态学报, 2003, 27(6): 733-741. 
[19] 金相灿，屠清瑛. 湖泊富营养化调查规范. 北京: 中国环境科学出版社, 1990.

[20] 庞清江, 李白英. 东平湖水体富营养化评价. 水资源保护, 2003, 19(5): 42-44.

[21] 张义科, 张雪松, 田玉梅. 利用浮游植物群落评价白洋淀水质的研究. 河北大学学报(自然科学版), 1997, 4(2): 39-46.

[22] Habib OA, Tippett R, Murphy KJ. Seasonal changes in phytoplankton community structure in relation to physico-chemical factors in Loch Lomond, Scotland. Hydrobiologia, 1997, 350: 63-79.

[23] Arhonditsis GB, Winder M, Brett MT et al. Patterns and mechanisms of phytoplankton variability in Lake Washington (USA). Water Research, 2004, 38: 4013-4027.

[24] Lau SSS, Lane SN. Nutrient and grazing factors in relation to phytoplankton level in a eutrophic shallow lake: the effect of low macrophyte. Water Research, 2006, 36: 3593-3601.

[25] Maraloni G, Tesolín G, Sacullo F et al. Factors regulating summer phytoplankton in a highly eutrophic Antarctic lake. Hydrobiologia, 2000, 432: 65-72 